\title{
Research on the Multiple Free Trade Areas under the Background of the TPP Effect of China's Economy and the Strategy Choices
}

\author{
Jin Qian \\ School of International Trade and Economics \\ Shandong University of Finance and Economics \\ Jinan, Shandong Province, China, 250014 \\ qianjin2012abc@126.com
}

\begin{abstract}
This article analyzes the multiple Free Trade Areas of China in the Asia-Pacific region, compares the TPP members with China's economic situation, and selects 19 countries and regions in the Asia-Pacific region in 2000-2014 panel data of 285 samples in order to find the effects of TPP and Chinese corresponding strategies. This paper uses the extended gravity model and carries on an empirical analysis of the fixed effects. The results show that TPP excludes China, China doesn't benefit because of the existence of the TPP, which is no significant statistically, at the same time, dominated by the United States and other developed countries to promote the TPP, will make China's FTA strategies in the Asia-Pacific region suffer negative impacts from the TPP. TPP includes major developing countries in the Asia-Pacific region, is bound to lead to outside China for regional economic cooperation, to avoid adverse effects. Therefore, China should timely adjust the regional economic strategies in order to reduce the TPP on the negative effect in China, carry out the TPP talks actively, at the same time, China should accelerate the construction of FTA, RCEP, make good use of all the way "One Belt One Road" strategy, actively carry out trade cooperation along the countries, and try to establish FTAAP. First is the sample, including Asia-Pacific region as a whole; Second is the method, extended gravity model can be used to analyze better.
\end{abstract}

Keywords-Free Trade Area; Fixed Effects; Gravity Model; Strategic Adjustment

\section{INTRODUCTION}

FTA (Free Trade Agreement, abbreviated as FTA), is a legally binding agreement concluded in different countries and economies, with the objective to promote production, goods and services under the scope of the Free Trade Area could flow freely, reduce the effects of tariff and non-tariff barriers, realize the economic complementary, and promote regional economic integration. The article introduces the process of Free Trade Area on the basis of the strategies of China's foreign trade in the Asia-Pacific region, outlook of FTAAP from the aspects of CAFTA, APEC, and RCEP respectively.

In the aspect of Chinese FTA strategies, since the reform and opening up, China has actively seek international trade cooperation and made efforts to push forward regional economic integration. By March 2016, China has involved in the Free Trade Areas for the number of 22 , among them, there are twelve in the Asia-Pacific region signed, respectively are mainland China, Hong Kong and Macao SAR, Peru, Chile, Pakistan, New Zealand, Singapore, the association of SouthEast Asian Nations (ASEAN), Costa Rica, just signed between China and Korea, Australia, and the association of South-East Asian Nations ("10 + 1"); three are negotiating, namely the second phase of China and Pakistan in FTA negotiations, China, Japan and Korea in negotiating FTA and the agreement of regional comprehensive economic partnership (RCEP).We can know from that, the above Free Trade Areas accounts for two-thirds of all the Free Trade Areas of construction in China, China attaches great importance to economic and trade relations with economies in the Asia-Pacific region.

Based on 2000-2014, 19 major economies in the AsiaPacific region and data stationary test of trade data, the innovation of gravity model and empirical research under the background of the Asia-Pacific multiple Free Trade Areas will help to offer effective countermeasures. The rest of the structure arrangements: second part is literature review; third part is the TPP and its member states and the comparative analysis of China's economy; fourth part is to establish model and data; fifth part is the data inspection and empirical analysis. Final is policy suggestions.

\section{LITERATURE REVIEW}

TPP is considered a free trade agreement of "comprehensive, open and high standards" in the 21st century, its development has important influence on today's world economy. Recently, because of the economic situation in the Asia-Pacific region, TPP is becoming the focus in attention. Increase in the influence of TPP in the Asia-Pacific region, because of its aspects of members' requirements is higher than the average level of free trade agreements, make TPP form a significant investment in location effects. At present, China is the world's second largest economy and Asia's largest economy, Chinese economic growth is not efficiently an important factor to join the TPP, on the contrary, TPP will be shut out of China for the Asia-Pacific region's economic stability and sustainable trade of development in constituting a major challenge. 
TPP in the academic research of the majority in the United States in 2009 was intervened in the TPP negotiations as a starting point, from the general situation of TPP, economic effects, strategic strategies and other aspects of research. In terms of TPP profiles, Zhao (2014) analyzed TPP potential threat of China's export industries and countermeasures research, argued that China should actively adjust the industrial structure to adapt to the development of economy [1].

In terms of economic effect, some scholars through the analysis of TPP in the negotiation process compared with the economic research among member states, Puga made use of Krugman's (1991) "Core-Periphery" model, from the angle of new economic geography, thought that trade liberalization would lead to the industry agglomeration of members, which influenced the development of economy. Baldwin, Venables (1995) regarded the influence in the spatial distribution of free trade agreements among members as a "position effect" [2]. Martin et al. (1995) put forward their own capital model on the basis of this, thought the production of factors among countries could flow by their own, the output of capital would flow back to the capital in exporting countries [3].

There are some scholars also using econometric models, Liu and Xin (2015) used the GTAP model to study the effects of TPP for free trade area among China, Japan and Korea, thought TPP hurt China's economy, and the effects increased with the increase of number in the TPP members. In terms of policy strategies [4]. Lv (2011) analyzed the characteristics of TPP, thought America had many aspects of motivation to join the TPP negotiations, to return to Asia-Pacific and build new Asia-Pacific rules; to lead TPP and to get as much as economic benefits; to make an attempt to weaken the influence of other FTAs in the Asia-Pacific region and improve the U.S. economic power; and realize economic Layout in the AsiaPacific region, etc [5].

\section{Member States OF TPP AND THE COMPARATIVE ANALYSIS IN CHINA'S ECONOMY}

Trans-Pacific Partnership Agreement (TPP), is known as Asia's "Economic NATO", formerly known as the TransPacific Strategic in Economic Partnership Agreement (abbreviated as P4). In 2009, the Obama administration announced in joining the TPP negotiations that TPP could have important effect in the economic growth in the United States. Since then, countries such as Australia, Peru and Vietnam joined the negotiations, thus achieved the change of P4 to P8. TPP negotiation was launched in March 2010, mainly composed of two parts: intellectual property in protection rules and importing tariffs in consultation, etc. TPP as U.S. dominates, from originally small free trade negotiation evolves into a highly political organization, contains 12 economies in the Asia-Pacific region of trade talks. On October 5, 2015, TPP made substantial breakthrough, namely the 10 member states agreed on the content of the terms of the agreement preliminary. On February 4, 2016, 12 countries officially signed in Auckland for Trans-Pacific partnership (TPP) protocol. Because TPP is broad, the degree of liberalization is higher, and has strong further reading in trade agreements, so it is called "High Threshold" form of comprehensive economic and trade by some countries. The agreement covers requirements of rules in origin, trade in services, technical barriers and remedies, animal and plant quarantines, intellectual property rights, labor standards and environmental problems, government procurements, and issues such as competition strategies. It is within the scope of high specifications of Free Trade Agreements.

\section{ESTABLISH MODEL AND DATA}

\section{A. Theoretical Model and Variables in Selection}

This paper analyzes with gravity modal. Along with advance of the global economy, the application of gravity model with the promotion, many scholars in the study of the gravity model expand the model, such as Leamer (1974) [6]for the first time considered per capita in income level; Bergstand (1985)[7]added the exchange rate factor into the model; Linnemann (1996) [8] was the first one to introduce demographic factors and virtual variables to the model ;Egger (2002) argued that gravity regression model should consider factors such as choice of time, continuous data, estimation in methods and so on [9].

At present, the gravity model is widely used in the analysis of international trade, especially the trade in potential power among different countries, in practice to better explain the correlations and economic phenomenon in economic trade, and it is usually used to calculate trade power and economic relationships in different countries. Chen and $\mathrm{Li}$ (2010) considered the nonlinear factors of gravity model [10]:

$$
\ln I M_{i j}=c+\alpha_{1} \ln \left(G D P^{*} G D P\right)+\alpha_{2} \ln D i j+\sum_{k=1}^{n} \beta_{k} d u m m y_{k}+\varepsilon
$$

Zhou (2012) compared with the perspective of static and dynamic aspects, and used language and colonies such as virtual variables [11]; Lv and Zheng (2013) took per capita as GDP variables into account [12]:

$$
L n T_{i j}=c+\beta_{1} L n D_{i j}+\beta_{2} L n Y_{i} Y_{j}+\beta_{3} L n N_{i} N_{j}+\beta_{4} C O M_{i j}+U_{i j}
$$

Jin and Yang (2015) introduced impact of the financial crisis [13]. Through the above literature reviews, combined with the research in the direction of this article, the author selects variables level of economic output (GDP), spatial distance, foreign trade in dependence and virtual variables such as trade policies, trade policies includes whether belong to the developed countries, whether to sign bilateral FTA and whether belong to APEC or TPP members, so the model is built as follows:

$$
\begin{aligned}
\log T R A D E_{i j t}= & \beta_{0}+\beta_{1} \log \left(G D P_{i t} G D P_{j t}\right)+\beta_{2} \log D I S T_{i j}+\beta_{3} O P E N_{j t}+\beta_{4} D C_{j} \\
& +\beta_{5} F T A_{i j t}+\beta_{6} A P E C_{j t}+\beta_{7} T P P_{j t}+\mu_{i j t}
\end{aligned}
$$

From above, $\mu_{i j t}$ is random error term.

This article selects 19 countries and regions in the AsiaPacific region in 2000-2014 panel data of 285 samples including Asia, Russia, Korea, Japan, Thailand, Singapore, 
Vietnam, the Philippines, Malaysia, Indonesia and Cambodia. North-America region of the United States, Canada and Mexico; Latin America are Colombia, Peru, Ecuador and Chile; Oceania region of New Zealand and Australia, is a total of 19 countries or areas as samples. These countries are not only representative countries in the Asia-Pacific region, but also Chinese major trading partners in the Asia-Pacific region, at the same time, these economies are located in the Pacific rim, a widely distributed, has a strong representative.

\section{DATA IN TEST AND EMPIRICAL ANALYSIS}

\section{A. Data in Test}

This paper uses unit root test and cointegration test to test stationarity of the panel data and correlation, concrete analysis is as shown below: Finally, complete content and organizational editing before formatting. Please take note of the following items when proofreading spelling and grammar:

1) Unit Root Test

About the unit root test of panel data (ADF test), Levin and Lin (1993) found the Gaussian distribution, which played an important role in the estimation of testing data in heteroscedasticity. Since then, Levin et al., (2002) improved the above research, LLC unit root test method was proposed, and this approach allowed different intercept and time trend. Maddala and $\mathrm{Wu}$ (1999) proposed the ADF Fisher in testing method. In order to well test data in stationarity, this article uses two methods of panel data namely the same root unit root LLC (Levin-Lin-Chu) test and different root unit root FisherADF test, if unit root null hypothesis is declined to exist in the two kinds of inspection, then the sequence is stationary, on the contrary, the opposite is not stationary, see table 1 .

TABLE I. ADF TEST, LLC TEST OF THE MODEL

\begin{tabular}{|c|c|c|c|c|}
\hline Variables & $\begin{array}{c}\text { Testing type } \\
(\mathrm{C}, \mathrm{T}, \mathrm{L})\end{array}$ & ADF testing & LLC testing & Conclusion \\
\hline \multirow{2}{*}{$\log T R A D E_{i j t}$} & $(\mathrm{C}, 0,0)$ & $\begin{array}{c}0.028 \\
(1.000)\end{array}$ & $\begin{array}{c}16.908 \\
(1.000)\end{array}$ & Non-stationary \\
\hline & $(\mathrm{C}, 1,0)$ & $\begin{array}{c}126.279 * * * \\
(0.000)\end{array}$ & $\begin{array}{c}-11.188 * * * \\
(0.000)\end{array}$ & Stationary \\
\hline \multirow{2}{*}{$\log \left(G D P_{i t} G D P_{j t}\right)$} & $(\mathrm{C}, 0,0)$ & $\begin{array}{c}0.003 \\
(1.000)\end{array}$ & $\begin{array}{c}58.794 \\
(1.000)\end{array}$ & Non-stationary \\
\hline & $(\mathrm{C}, 1,0)$ & $\begin{array}{l}72.190 * * * \\
(0.000)\end{array}$ & $\begin{array}{l}-6.179 * * * \\
(0.000)\end{array}$ & Stationary \\
\hline \multirow{2}{*}{$O P E N_{j t}$} & $(\mathrm{C}, 0,0)$ & $\begin{array}{r}41.541 \\
(0.319)\end{array}$ & $\begin{array}{c}-1.7511^{* *} \\
(0.040)\end{array}$ & Non-stationary \\
\hline & $(\mathrm{C}, 1,0)$ & $\begin{array}{c}180.110 * * * \\
(0.000)\end{array}$ & $\begin{array}{c}-15.125 * * * \\
(0.000)\end{array}$ & Stationary \\
\hline
\end{tabular}

Note: The inspection type $(\mathrm{C}, \mathrm{T}, \mathrm{L})$ in distribution is expressed of the constant term, trends and lag time periods. $* * *$, **and* are respectively showed in $1 \%, 5 \%$ and $10 \%$ significance level through the test, corresponding $\mathrm{P}$ values are shown in the brackets.

\section{B. Empirical Analysis and Conclusion}

There are mainly three kinds of models in panel data analysis: fixed effect model, random effect model, and mixed effect model. The utility of fixed effect and random effect can be in Hausman test, first to analyze with random effect, and then use Hausman test, if it refuses to null hypothesis, we should use fixed effect; conversely if accept the null hypothesis, we should use random effect.
This paper uses Eviews9.0 software, panel data of gravity model and Hausman test to have an analysis of the fixed effects model, p-value is less than 0.01 , so the fixed effect model is adopted. This article applies the method of stepwise regression in turn of increasing the number of variables, analyzes under different model of bilateral trade among China and sample countries in the Asia-Pacific region, which can impact on Chinese FTA strategies.

1) Regression Model with Fixed Effects

Using the formula to have the empirical research for China's bilateral trade, see table 2:

TABLE II. FIXED EFFECTS USED IN REGRESSION MODEL

\begin{tabular}{|c|l|l|l|l|c|}
\hline Variables & Model 1 & Model 2 & Model 3 & Model 4 & Model 5 \\
\hline \multirow{2}{*}{$\log \left(G D P_{i t} G D P_{j t}\right)$} & $0.896^{* * *}$ & $\begin{array}{l}0.874^{* * *} \\
(25.871)\end{array}$ & $\begin{array}{l}0.629 * * * \\
(23.894)\end{array}$ & $\begin{array}{l}0.844^{* * * *} \\
(27.729)\end{array}$ & $\begin{array}{c}0.614^{* * *} \\
(21.824)\end{array}$ \\
\hline \multirow{2}{*}{${\log D I S T_{i j}}$} & $-0.271^{* * *}$ & $-0.284^{* * * *}$ & $-0.573^{* * *}$ & $-0.578^{* * *}$ & $-0.566^{* * * *}$ \\
& $(-5.022)$ & $(-5.134)$ & $(-14.195)$ & $(-10.292)$ & $(-12.699)$ \\
\hline \multirow{2}{*}{$O P E N_{j t}$} & $0.007^{* * *}$ & $0.007^{* * *}$ & $0.004 * * *$ & $0.005^{* * * *}$ & $0.004^{* * *}$ \\
& $(12.096)$ & $(11.347)$ & $(8.484)$ & $(8.927)$ & $(8.190)$ \\
\hline \multirow{2}{*}{$T P P_{j t}$} & & & & & 0.108 \\
& & & & & $(1.0138)$ \\
\hline
\end{tabular}




\begin{tabular}{|c|c|c|c|c|c|}
\hline \multicolumn{6}{|c|}{ Table II, cont. } \\
\hline$F T A_{i j t}$ & & & & $\begin{array}{l}0.578 * * * \\
(4.161)\end{array}$ & $\begin{array}{c}-0.218^{*} \\
(-1.654)\end{array}$ \\
\hline$A P E C_{j t}$ & & & $\begin{array}{l}1.918^{* * *} \\
(18.116)\end{array}$ & $\begin{array}{l}1.517 * * * \\
(11.280)\end{array}$ & $\begin{array}{l}1.931 \text { *** } \\
(18.159)\end{array}$ \\
\hline$D C_{j}$ & & $\begin{array}{c}0.116 \\
(1.062) \\
\end{array}$ & $\begin{array}{c}0.116 \\
(1.579) \\
\end{array}$ & $\begin{array}{l}-0.254 * * * \\
(-2.664)\end{array}$ & $\begin{array}{r}0.148^{*} \\
(1.894) \\
\end{array}$ \\
\hline Adjusted $\mathrm{R}^{2}$ & 0.843 & 0.843 & 0.930 & 0.879 & 0.930 \\
\hline F statistics & 90.897 & 85.951 & 198.864 & 345.156 & 180.637 \\
\hline Samples & 285 & 285 & 285 & 285 & 285 \\
\hline
\end{tabular}

Note: Respectively in $1 \%, 5 \%$ and $1 \%$ significance level through the test, brackets as the corresponding $\mathrm{t}$ value, as listed in the table below.

As shown in table 2, the empirical analysis of this article adopts the method in analysis, model 1 considers gross domestic product (GDP), geographic distance (DIST) and foreign trade dependence (OPEN) as three independent variables, which all through the test on the $1 \%$ significant level, the coefficient of geographic distance variable is negative, this confirms expected symbols, namely the closer in the geographic distance among China and others, the more conducive to carry out bilateral trade in the Asia-Pacific region; otherwise, it is not conducive to develop bilateral trade. This further reflects the FTA strategies in China and tends to cooperate with neighboring countries, such as China and Korea have just signed Free Trade Area, and be in talks among China, Japan and Korea for Free Trade Area, etc; Free Trade Area has a positive impact on export trade, and GDP is also in line with expectations. From the perspective of the coefficient of variable OPENjt, its value is small, but statistically significant under $1 \%$ level, this shows in the Asia-Pacific region, with the advancement of economic integration, the bilateral trade among countries has become the new normal.

Model 2 adds DCj variable, from the result, it does not cause several other variables regression in the result of significant change, but it doesn't pass the significance level of $10 \%$.This means that developed countries or not is not the necessary condition to develop bilateral trade in the AsiaPacific region, demonstrates cooperation among developing countries in the Asia-Pacific region is given priority to the reality.

Model 3 introduces the influence of APECjt, under 1\% significance level through the test and the coefficient is positive, this demonstrates APEC members have positive effect on members' economic trade in the Asia-Pacific region, from the point of coefficient value, the value is quite large, it shows the Asia-Pacific economic cooperation (APEC) can effectively promote regional trade. The introduction of APECjt does not cause other variables significantly as a result, it shows that can jointly with the other factors affecting the regional economic integration.

Model 4 adds FTAijt on the basis of the model 3, the variable through the test of $1 \%$ significance level, shows that free trade agreements signed among China and other countries are conducive to the development of bilateral trade and economic integration in the Asia-Pacific region. At the same time, FTAijt is significantly without change, its value slightly lower, under the common effect on FTA and APEC, look from the result of regression, the effect is more than a single form.

Model 5 adds TPPjt, under the influence of the variable, FTA effect for China is negative, to some extent, this shows TPP against Chinese Free Trade Area, at the same time, DCj passes $10 \%$ significance level, shows that the United States as the leading developed countries has more obvious in the role of TPP. TPPjt passes no significance level test, shows that TPP excludes trading powers such as China will hinder the development of its own.

\section{2) Comparative Analysis of Fixed Effect and Random} Effect

In the table below is to compare fixed effect with random effect.

TABLE III. FIXED EFFECTS AND RANDOM EFFECT

\begin{tabular}{|c|c|c|}
\hline Variables & Fixed effect & $\begin{array}{c}\text { Random } \\
\text { effect }\end{array}$ \\
\hline $\log \left(G D P_{i t} G D P_{j t}\right)$ & $\begin{array}{l}0.614 * * * \\
(21.824)\end{array}$ & $\begin{array}{l}0.799 * * * \\
(32.816)\end{array}$ \\
\hline $\log D I S T_{i j}$ & $\begin{array}{l}-0.566^{* * * *} \\
(-12.699)\end{array}$ & $\begin{array}{l}-0.638 * * * \\
(-14.523) \\
\end{array}$ \\
\hline$O P E N_{j}$ & $\begin{array}{l}0.004 * * * \\
(8.190)\end{array}$ & $\begin{array}{l}0.004 * * * \\
(9.866)\end{array}$ \\
\hline$T P P_{j t}$ & $\begin{array}{c}0.108 \\
(1.0138) \\
\end{array}$ & $\begin{array}{l}0.565 * * * \\
(5.884) \\
\end{array}$ \\
\hline$F T A_{i j t}$ & $\begin{array}{r}-0.218 \\
(-1.654) \\
\end{array}$ & $\begin{array}{c}0.153 \\
(1.196) \\
\end{array}$ \\
\hline$A P E C_{j t}$ & $\begin{array}{l}1.931 \text { *** } \\
(18.159)\end{array}$ & $\begin{array}{l}1.567 * * * \\
(15.262)\end{array}$ \\
\hline$D C_{j}$ & $\begin{array}{c}0.148^{*} \\
(1.894)\end{array}$ & $\begin{array}{l}-0.212 * * * \\
(-2.904)\end{array}$ \\
\hline Samples & 285 & 285 \\
\hline
\end{tabular}

From table 3 we can know that three methods on each coefficient in value and significance level are basically the same as a whole, just exist a slight difference in t-value. In terms of t-value, random effect is better, and from the actual effect of trade, fixed effect is superior to random effect. This is because TPP excludes China, there is no benefit in China because of TPP, no significant statistically; At the same time, dominated by the United States and other developed countries TPP agrees upon will make Chinese FTA strategies in the Asia-Pacific region affected negatively, TPP includes major developing countries in the Asia-Pacific region excluding China will lead adverse effects. In the short term, TPP would give China's regional economic and trade a certain degree of 
impact, but in the long term, in the process of regional economic integration in the whole world, any of the multilateral trade could not exclude non members outside the system, otherwise it will hinder its economic development.

\section{CONCLUSION}

Through the above analysis, the conclusion of this paper is TPP agreement will be an adverse effect on China's trade pattern in the Asia-Pacific region, China cannot obtain positive effect from it, and suffers economic losses from TPP. Though this influence is not enough to cause a large wave of China's economy, but for the comprehensive factors under the influence of the multiple Free Trade Areas, China as a large trading nation in the world but not in the regional economic of win-win economic cooperation with other countries, which will hinder the Asia-Pacific regional development in economic integration, and will be unfavorable to the development of global economy and economic integration.

\section{POLICY SUGGESTIONS}

In terms of trade cooperation, facilitate the RCEP into effect. RCEP will help reduce TPP influence on China's economy, China's foreign trade is open, cooperation and winwin style through economic cooperation to create development opportunities for every country. China should improve the quality of economic development in the Asia-Pacific region and RCEP can provide good guarantee for it. Because some members are both in RCEP and TPP, the achievement is not only beneficial to reduce TPP to cause trade diversion effect in China, but also can build a new system of economic and trade cooperation in the Asia-Pacific region to provide the direction. RCEP will be helpful to solve the high cost problem in "Wheel-Spokes Effect" of " $10+1$ " framework, to combine into a whole, the agreement for the bilateral trade, decreases the cost of trade and economic cooperation.

In the development of Free Trade Area, China should continue to deepen with the association of Southeast-Asian nations and major trading partners in the Asia-Pacific region's economic intercourse, accelerate the construction process in Free Trade Areas such as FTA, RCEP, make good use of "One Belt One Road" strategy, actively carry out trade cooperation with countries along the strategies and try to establish FTAAP.

In terms of strategic decisions, China should pay attention to the economic trends in the Asia-Pacific region, particularly in the United States in the Asia-Pacific region's strategic changes, timely adjust regional economic policies in order to reduce the TPP on the negative impact. At the same time, China, Japan and Korea in FTA negotiations should be accelerated for East-Asia's economic integration. China needs to encourage in the positive economic confrontation in the Pacific region, avoid the conflict with the United States. Huge potential market is in the Asia-Pacific region, at the same time, also facing the imbalance of development, which requires the utility of economic complementarities in industry with the TPP member states. China should make efforts to reform the economic system and mechanism to adapt to the needs of economic development, adjusting industrial structure and transformation of economic development strategies.

China should seek to develop new trade rules in the area of the initiative within multiple Free Trade Areas in the AsiaPacific economic environment. Trade among China and the TPP members has some certain complementarity, in the accelerating process of FTA negotiations with Asia-Pacific countries, drawing on the successful experience in existing. In the TPP negotiations on technology, regulations and supervision mechanism, China should adjust timely actual situations of the national trade and regional economic development plans.

\section{REFERENCES}

[1] Na Zhao. TPP has potential threat to China's export industry and countermeasures[J]. Journal of world economic study, 2014,02:23-28.

[2] Baldwin R E, Venables A J. Regional Economic Integration[M]. Handbook of International Economics. Amsterdam: North, Holland. 1995.

[3] Martin P, Ottaviano G. The Geography of Multi-speed Europe[R]. CEPII Research Center Working Papers No.1995.

[4] Pengchun Liu, Huan Xin and Cheng Chen. Feasibility and effect of the development path are in research among China, Japan and Korea in TPP -based on the analysis of GTAP model [J]. Journal of international trade issues, 2015, 11:96-108.

[5] Jianren Lv. Research on the United States joining to TPP [J]. Journal of international trade issues, 2011,01:43-52.

[6] Leamer. The Commodity Composition of International Trade in Manufactures: An Empirical Analysis[J].Oxford Economic Papers, 1974(26):350-374.

[7] Bergstrand.The Gravity Elation in International Trade:Some Micro economic Foundations and Empirical Evidence[J].The Review of Economic and Statistics, 1985,20(2)

[8] Linnemann H.An Econometric Study of International Trade Flows [M].Amsterdam:Elsie, 1966.

[9] Egger,P. An Economic View on the Estimation of Gravity Models and the Calculation of Trade Potentials. The World Economy,2002( 25): 297-312.

[10] Yuanyuan Chen, Kunwang Li, Haining Wang. Free Trade Areas are under the effect of import and export trade based on international data analysis of gravity model [J]. Journal of world economic studies, 2010,06: 39-45.

[11] Nianli Zhou. Whether "Regional Trade Arrangements" can effectively promote the developing economies in service exports $[\mathrm{J}]$. Journal of world economy, 2012, 11:88-111.

[12] Hongfen Lv, Yali Zheng. Research of China-Chile Free Trade Area within the gravity model of trade effects[J]. Journal of international trade issues, 2013, 02:49-57.

[13] Zhuiqiao Jin, Fengmin Yang. The empirical study is on the current situation and potential trade between China and Korea [J]. Journal of world economic studies, 2015,01:81-90. 